\title{
STRANAČKA POLITIKA U VUKOVARU 1990-1991.
}

\author{
Vladimir Filipović \\ Libertas međunarodno sveučilište \\ E-mail:vfilipovic@gmail.com
}

\author{
DOI: 10.20901/an.16.05 \\ Pregledni rad \\ Prihvaćeno: rujan 2019.
}

\begin{abstract}
Sažetak U članku se analizira lokalna politika u općini Vukovar od pluralizacije političkog života u Hrvatskoj početkom 1990. do sloma demokratski izabranih lokalnih političkih institucija u svibnju 1991. To razmjerno kratko razdoblje obilježila je snažna politička polarizacija između dviju najbrojnijih nacionalnih zajednica, $\mathrm{Hr}$ vata i Srba, u općini. U tom su procesu tri političke stranke - Savez komunista Hrvatske-Stranka demokratskih promjena, Hrvatska demokratska zajednica i Srpska demokratska stranka - bile glavni akteri nacionalne mobilizacije i političkog života u Vukovaru.
\end{abstract}

Ključne riječi Vukovar, političke stranke, lokalni izbori, stranačka politika

\section{Uvod}

Stranačka politika u Vukovaru prije početka bitke za grad relativno je slabo poznata. Osnovni podaci mogu se naći u znanstvenoj (Marijan 2013), publicističkoj i memoarskoj literaturi (Runtić 2010; Ivanda 2010; Mirković-Nađ 2011), te u djelima koja imaju "znanstveni okvir", ali ponajprije služe izgradnji nacionalnih naracija o ratu (Karaman i dr. 1994; Jurčević i dr. 2004). Ovaj bi rad trebao pridonijeti razumijevanju predratnoga stranačkog i političkog života u Vukovaru koji je bitno odredio kasnija ratna zbivanja. U rekonstrukciji se oslanjam na tiskane medije, ponajprije na Vukovarske novine (VN), i na dokumentaciju o sudskim postupcima na Međunarodnom sudu za ratne zločine u bivšoj Jugoslaviji u Haagu.

\section{Savez komunista Vukovara}

U socijalističkoj Jugoslaviji Vukovar je često opisivan kao "bastion" jugoslavenstva i socijalizma. Lokalni i državni partijski dužnosnici isticali su činjenicu da je u Vukovaru održan 2. kongres Komunističke partije Jugoslavije (KPJ) i da su u vukovarskoj općini "u bratstvu i jedinstvu" živjeli pripadnici dvadeset četiri naroda. Političkim i društvenim životom grada do kraja 1989. potpuno je dominirao Savez komunista, a u dostupnim izvorima nema tragova otpora toj dominaciji (Cvikić 2016).

Savez komunista Hrvatske (SKH) imao je u Vukovaru brojno članstvo koje se s vremenom smanjivalo. Potkraj 1985. općinska organizacija imala je 6.048, a potkraj 1988. godine 5.391 članova. Najviše se smanjivao broj mlađih i obrazovanih članova, dok su stariji 
članovi partiju većinom napuštali svojevoljno. Udio Hrvata u članstvu bio je manji, a udio Srba veći od njihovih udjela u stanovništvu: sredinom 1989. član partije bio je svaki osmi Srbin i svaki osamnaesti Hrvat (VN, 9. rujna 1989). $\mathrm{Na}$ smanjenje privlačnosti partije zacijelo je utjecala i teška ekonomska kriza u vukovarskoj općini u drugoj polovici osamdesetih godina. Ekonomski rezultati velikih poduzeća bili su katastrofalni, posebice kombinata Borovo koji je činio 55 posto bruto društvenog proizvoda općine, pa su u tvornici učestali štrajkovi i nemiri (Cvek, Ivčić i Račić 2015; Filipović 2018).

Vukovarski kraj bio je zemljopisno povezan sa Srbijom, to jest s Vojvodinom, što je utjecalo na oblikovanje sličnih obrazaca socijalnoga i kulturnog života s dviju strana granice tijekom povijesti. Međurepubličku suradnju poticali su i lokalni kulturni partijski radnici, a beogradski i novosadski mediji umnogome su oblikovali političko ozračje u vukovarskom kraju, posebice među Srbima. Tijekom svrgavanja političkog vodstva Vojvodine 1988. ojačani su kontakti predsjednika Saveza komunista Srbije (SKS) Slobodana Miloševića i njemu odanih Srba u vukovarskom SKH. ${ }^{1}$

Miloševićeva politička platforma i nacionalističke ideje s političke i kulturne scene Srbije postali su vidljivima 1989. Mjesni odbori sela sa srpskim stanovništvom počeli su otvoreno zastupati političke ideje koje su bile na tragu Memoranduma Srpske akademije nauka i umetnosti (SANU). Tako su u proljeće 1989. iz Bobote poručili kako su Srbi u Hrvatskoj zapostavljeni, a glavnim krivcima za teško stane u Jugoslaviji proglašeni su Ustav 1974. i Albanci (VN, 15. travnja 1989). Slične su se poruke čule sa zbora mještana Pačetina (VN, 9. prosinca 1989). Srbi iz sela vukovarske

1 ICTY/Cases: Hadzic(IT-04-75)/Witness: Borivoje Savić. općine tražili su obnovu srpskih nacionalnih institucija, poput Matice srpske, i nacionalnih simbola, poput ćirilice, kao i jačanje društvene uloge Srpske pravoslavne crkve. Protivili su se demokratskim promjenama, posebno onima koje su poticane iz Zagreba. Najburnije su reagirali na osnivanje novih političkih stranaka, osobito Hrvatske demokratske zajednice (HDZ), u čemu su vidjeli "običnu obnovu ustaštva koja vodi kaosu". Na sastanku predstavnika mjesnih zajednica Trpinje, Bobote, Klisa, Lopovače, Pačetina i Bršadina odbačeni su prijedlozi o konfederaciji ili državnoj neovisnosti Hrvatske te je istaknuto da je Hrvatska domovina Srba samo u sklopu Jugoslavije (VN, 9. prosinca 1989).

Većina vodećih srpskih komunističkih političara u Vukovaru uglavnom je podupirala Miloševićevu politiku. Službeno su podržavali postojeći federativni model, ali i borbu protiv "svih uzroka i pojava koji ugrožavaju bratstvo i jedinstvo naših naroda", pri čemu su mislili na albanski separatizam i iredentizam (VN, 28. siječnja i 4. ožujka 1989). Delegacija Općinskog komiteta SKH sudjelovala je u lipnju 1989. u proslavi 600. obljetnice bitke na Kosovu i vratila se prepuna pozitivnih dojmova o "veličanstvenoj atmosferi" i Miloševićevu govoru (VN, 1. srpnja 1989).

Velik potres u općinskoj organizaciji SKH izazvao je 14. kongres SKJ u siječnju 1990. Nakon što su delegati SKH napustili skup, Općinski komitet objavio je kako "ne može prihvatiti veći dio stavova CK SKH" i kako je protiv "jačanja samodovoljnosti i autonomnosti republičkih SK", ustvrdivši da CK SKH uopće ne sluša bazu koja se protivila napuštanju kongresa SKJ (VN 27. siječnja i 10. veljače 1990). Od četiri delegata općine Vukovar na kongresu, troje je ostalo nakon što je delegacija SKH napustila Beograd (VN, 2. lipnja 1990). U stavovima objavljenima 7. veljače 1990. 
piše da se Općinski komitet zauzima "za jedinstven SKJ, ali ukoliko bi SKH i dalje zadržao svoj dosadašnji odnos prema SKJ, i OK SKH Vukovar bi slijedio liniju odnosa SKH-SKJ prema CK SKH" (VN, 7. i 10. veljače 1990). Ukratko, odvoji li se SKH od SKJ, općina Vukovar može se odcijepiti od Hrvatske.

$\mathrm{U}$ napetoj atmosferi nakon 14 . kongresa SKJ i raspisanih izbora za Sabor SR Hrvatske, predstavnici mjesnih zajednica srpskih sela u veljači 1990. tražili su miting za "jedinstvenu Jugoslaviju" prema uzoru na Miloševićeve mitinge u Srbiji. Miting je trebala organizirati općinska organizacija Socijalističkog saveza radnog naroda Hrvatske (SSRNH) na Dudiku, kod spomen-obilježja žrtvama ustaških pokolja, da "upozorimo na to što nam se sprema" (Pekić 1995: 61). Općinski komitet bio je suzdržan prema toj ideji. Isprva se izgovarao tehničkim problemima da bi na kraju zaključio kako bi u "našoj višenacionalnoj sredini jednonacionalno okupljanje moglo poremetiti još uvijek relativno stabilne međunacionalne odnose" (VN, 17. veljače 1990). Na sjednici lokalnog ogranka SSRN-a, a zahvaljujući potpori mjesnih zajednica s većinskim hrvatskim stanovništvom, odbijen je zahtjev da se održi miting (VN, 3. ožujka 1990). Eventualna organizacija mitinga prepuštena je mjesnim zajednicama koje su ga predložile. Upozoreno je na to kako su organizaciju mitinga poticale osobe iz Vojvodine koje su bile odane Miloševiću. Neki nisu shvaćali što stoji iza zahtjeva za mitingom pa su ga dobronamjerno podržavali. Tada malo poznati novinar Siniša Glavašević objavio je tekst u kojemu je napisao kako mještani srpskih sela "s još nezaboravljenim strahom podsjećaju na zdravu pamet" i dodao: "Ono što predlažu spomenute MZ posve je jednostavan i lako primjenjiv recept koji bi rado kušao svaki prosječan građanin SFRJ" (VN, 17. veljače 1990). Iako Glavaše- vićev tekst nije potpuno jasan, očito je podržao ideju o mitingu. Više je mogućih razloga zbog kojih Općinski komitet nije podržao miting, a jedan je zasigurno bila želja da se ne zaoštravaju odnosi s CK SKH uoči izbora.

Iako su u većini srpskih sela partijske organizacije bile raspuštene $\mathrm{i}$ ona nisu više bila pod kontrolom CK SKH, još nisu osnivane druge stranke (Pekić 1995: 62). Srbi koji su prihvaćali Miloševićeve ideje procijenili su da nemaju dovoljno vremena da dobro organiziraju Srpsku demokratsku stranku (SDS) ili neku drugu stranku. Osim toga, osnivanje novih stranaka vodilo bi "rasipanju srpskih glasova". ${ }^{2}$ Dio Srba, pogotovo u gradu, bio je još uvijek "neosviješten" i vjerovao je u Jugoslaviju (Pekić 1995: 62). SKH je imao kvalitetnu infrastrukturu, mogli su računati na sve "srpske", dio "hrvatskih" i glasove pripadnika drugih naroda u općini kojih nije bilo malo. SDS nije osnovan u Vukovaru prije izbora djelomice i zato što srpska pobuna u Hrvatskoj nije bila autentična nego uvezena iz Srbije (Žunec 2007). Prema toj interpretaciji, Srbi su dobili naputke iz Beograda da ne osnivaju svoju stranku prije izbora.

Vukovarski SKH-SDP u izbore je ušao naoko jedinstven i s izbornim programom sastavljenim prema uputama iz Zagreba. Programski se zauzimao za prijelaz u demokraciju i protivio se nacionalizmu i razbijanju jugoslavenske države. Podržavao je razvoj tržišne ekonomije i politiku saveznog premijera Ante Markovića (VN, 14. travnja 1990). Zauzimao se za razvoj "demokratskog socijalizma" te isticao predanost procesima europskih integracija i federativnom uređenju Jugoslavije. Naglašavao je svoju predanost mirnome i skladnom suživotu svih naroda vukovarske općine, koji "nove snage" pokušavaju naru-

2 ICTY/Cases: Dokmanovic(IT-95-13a)/Witness: Goran Hadzic. 
šiti. Predstavljao se kao stranka koja se protivi "onima koji se prepoznaju prema nacionalnim bojama" (VN, 17. ožujka 1990). Nudio je status quo u raspodjeli moći na razini općine.

\section{Hrvatska demokratska zajednica}

Hrvatska demokratska zajednica (HDZ) u jesen 1989. organizacijski se širila Slavonijom, a aktivnosti je ubrzavala s približavanjem izbora. U studenom 1989. osnovana je podružnica u Osijeku na čelu s Vladimirom Šeksom i Branimirom Glavašem (Knežević 2015: 162). O osnivanju vukovarskog HDZ-a postoji više nejasnih podataka. Pero Ćorić iz Šarengrada tvrdio je kako je u njegovoj kući 30. prosinca 1989. održan inicijalni sastanak na kojemu se razgovaralo o osnivanju HDZ-a u općini Vukovar. I Općinski komitet SKH imao je tu informaciju, kao i podatak da je 10. siječnja 1990. osnovan ogranak HDZ-a u Bapskoj (VN, 20. siječnja 1990). U razgovoru za vinkovački Hrvatski vjesnik (HV) 22. prosinca 1990. predsjednik vukovarskog HDZ-a Tomislav Merčep izjavio je kako se u stranku učlanio na poticaj jednog zidara iz Bapske koji mu je rekao da bi trebao ući u nju zato što je uvijek bio "veliki Hrvat".

Inicijalni sastanci za osnivanje HDZ-a u gradu Vukovaru održavani su početkom 1990. Najviše je uspjeha bilo u dijelovima grada, kakav je bila Mitnica, u kojima je živjelo više doseljenih Hrvata iz Hercegovine ${ }^{3}$ i u selima u kojima su Hrvati bili većina stanovnika i u kojima je bilo malo članova SKJ, kao u Bogdanovcima (Matković 1998: 17). Kako im vlasti nisu dopuštale da skupove održe u prostorima mjesnih zajednica, osnivači su se okupljali u kafićima, privatnim kućama i prostorijama koje im je ustupila

3 Izjava Pilipa Karaule, Video materijal: Bitka za Vukovar, ep 1. Raspad Jugoslavije. https://www.youtube.com/watch?v=RXe05UMkJnA\&t=1609s, uč: 1. ožujka 2019.
Katolička crkva. HDZ se poglavito obraćao osobama za koje je pretpostavljao da su se spremne pridružiti stranci (Radoš i Šangut 2011: 18). Pritom se o vodilo računa o tome jesu li te osobe slovile kao "veliki Hrvati", jesu li bili distancirani prema komunističkoj vlasti, jesu li imali pretke u oružanim snagama NDH, jesu li išli u crkvu i sl. ${ }^{4}$

Podružnice u mjesnim zajednicama ujedinile su se u gradsku organizaciju HDZ-a u veljači 1990. Predsjednik je postao građevinski inženjer Tomislav Merčep koji je živio u Bogdanovcima i bio zaposlen u Borovu. Premda je Merčep kazao da je prvi predsjednik HDZ-a u Vukovaru bio Josip Blažević, zvani Deda (HV, 22. prosinca 1989), ${ }^{5}$ on je dominirao vukovarskim HDZ-om. U Borovu Naselju djelovala je organizacija HDZ-a kojoj je na čelu bio sindikalist iz kombinata Borovo Blago Zadro. Premda je otprije održavao kontakte sa Šeksom i Glavašem, isprva se nećkao pristupiti stranci. U romantiziranoj biografiji Blage Zadre, Radoš i Šangut (2011) ne navode razloge tog "nećkanja".

U veljači 1990. vukovarski HDZ dovršio je organizacijski posao. U stranci je bilo relativno malo ljudi s političkim i upravljačkim iskustvom. U manjim sredinama poput Vukovara intelektualna elita izvan partije gotovo nije ni postojala. U članstvu su prevladavali slabo obrazovani pojedinci, radnici, mali obrtnici, seljaci i nezaposleni. Premda je Merčepova tvrdnja da je vukovarski HDZ imao sedam tisuća članova (HV, 22. prosinca 1989) vjerojatno bila pretjerana, zacijelo je imao nekoliko tisuća članova. Mnogi članovi nisu na HDZ gledali kao na političku stranku nego kao na svehrvatski pokret protiv komu-

4 ICTY/Cases: Dokmanovic(IT-95-13a)/Witness: Zdravko Vracaric.

5 ICTY/Cases: Hadzic(IT-04-75)/Witness: Pero Coric. 
nista i velikosrba (Marijan 2015: 209; Matković 1998: 15-16).

Vukovarski HDZ programski se definirao kao "nacionalna stranka hrvatskog naroda i svih drugih koji Hrvatsku osjećaju svojom domovinom". Zauzimao se za opće ljudske i demokratske slobode. Najavljivao je privatizaciju i denacionalizaciju u gospodarstvu te "kulturni i moralni preodgoj". Posebno je odjeknulo ono što je kazao Merčep: "HDZ dolaskom na vlast nikome neće oduzeti nijedno pravo, ali zato hoće sve beneficije koje nisu produkt rada, reda i moralnih načela... Nitko ne smije imati manje prava od hrvatskog naroda" (VN, 7. travnja 1990). Oni koji su se osjećali pogođenima ili prozvanima reagirali su burno i žestoko i prije no što je HDZ imao priliku ostvariti svoj program. Općinski komitet SKH-SDP-a ustvrdio je kako HDZ donosi "novi totalitarizam" i poništava demokratske vrijednosti. Svojom je dužnošću smatrao to da brani hrvatski narod od onih koji su mu pripisali neoustaštvo. Podržao je stav republičkog SKH-SDP-a o HDZ-u kao "stranci opasnih namjera". Lokalni SUBNOR zahtijevao je da se HDZ zabrani (VN, 10. ožujka 1990). Mnoge je uvjerene komuniste, najčešće Srbe, iritirala sama pojava neke druge stranke, pogotovo ako je imala hrvatski predznak.

HDZ je vladajućem SKH-SDP-u bio oštar ideološki suparnik. Bilo je jasno da je riječ o antikomunističkoj stranci, a Srbi i uvjereni komunisti smatrali su ga i ustaškom strankom (Glas Slavonije, 2. travnja 1990). U vukovarskom HDZ-u bilo je i bivših članova SKH, ali u vodstvu su dominirale osobe koje nisu bile članovi partije. Vukovarski HDZ posjećivao je mjesta na kojima su 1945. ubijani pripadnici poražene hrvatske vojske (HV, 22. prosinca 1990). Isticane su njihove žrtve za Hrvatsku, preuveličavan je broj žrtava i prizivana osveta. Nije istican odmak od ustaške ideologije i poli- tike, što je pridonosilo stvaranju dojma kod Srba da je HDZ "ustaška" stranka. Kako je HDZ istodobno prijetio narušavanjem statusa quo u raspodjeli moći, iza zabrinutosti zbog pojave stvarnoga ili izmišljenog ustaštva često su se skrivali strahovi od gubitka dotadašnje političke i društvene moći i statusa pojedinaca i društvenih skupina.

Članstvo u HDZ-u izjednačavano je s pripadnošću hrvatskoj naciji (Marijan 2015: 209). Oni koji nisu bili članovi ili pristaše HDZ-a nisu smatrani samo političkim suparnicima nego i lošim Hrvatima. Jedan pristaša stranke kazao je kako su svi vukovarski Hrvati koji ne glasuju za HDZ "odnarođeni, karijeristi i ljudi iz mješovitih brakova, čije je hrvatstvo zakržljalo" (Šimunović 2003: 30). Prošireno je bilo poistovjećivanje stranke i nacije, a kasnije i stranke i države.

HDZ je izbornu kampanju manje vodio u njemu nesklonima lokalnim medijima, a više plakatima i u neposrednim dodirima s građanima, obavljajući većinu posla "na terenu". Sva hrvatska sela bila su mobilizirana. Dok je, primjerice, na predizborni skup kandidata SKHSDP-a u Lovasu došlo nekoliko ljudi, na skup kandidata HDZ-a došli su svi mještani. ${ }^{6}$ Slično je bilo u Šarengradu, Bapskoj, Sotinu i drugima manjim hrvatskim selima. U selu Berak s mješovitim stanovništvom na predizbornom skupu HDZ-a izbio je sukob jer su okupljeni Srbi psovali okupljene i bacali jaja na njih, a veće je sukobe spriječila policija (Runtić 2010: 365).

Završni predizborni skup HDZ-a u središtu Vukovara prošao je u uzavreloj atmosferi i uz veliko policijsko osiguranje. Okupio se veći broj ljudi, vjerojatno Srba, koji su zviždali dok se izvodila hrvatska himna i skandirali "Jugoslavija,

6 ICTY/Cases: Dokmanovic(IT-95-13a)/Witness: Milenko Milinkovic. 
Tablica 1. Rezultati izbora za Skupštinu općine Vukovar: broj mandata

\begin{tabular}{lcccc}
\hline & $\begin{array}{c}\text { Društveno- } \\
\text { političko } \\
\text { vijeće }\end{array}$ & $\begin{array}{c}\text { Vijeće } \\
\text { mjesnih } \\
\text { zajednica }\end{array}$ & $\begin{array}{c}\text { Vijeće } \\
\text { udruženog } \\
\text { rada }\end{array}$ & $\begin{array}{c}\text { Skupština } \\
\text { općine } \\
\text { ukupno }\end{array}$ \\
\hline SKH-SDP & 14 & 19 & 30 & 63 \\
HDZ & 9 & 12 & 5 & 26 \\
Neovisni & 2 & 4 & 19 & 19 \\
SSRNH & & 1 & 1 & 7 \\
SSOH & & & & 1 \\
\hline
\end{tabular}

Jugoslavija". Glavaš je pozdravio skup u "hrvatskom Vukovaru" uz glasan pljesak sudionika i zviždanje prosvjednika. ${ }^{7}$ Šeks je pozvao i Hrvate i Srbe da poštuju suverenost Hrvatske kao zajedničke domovine u kojoj će imati jednaka demokratska prava i slobode. Oni kojima se ne sviđa što je ovo Hrvatska, kazao je Šeks, "neka ide preko Dunava". ${ }^{8}$

\section{Izbori 1990.}

Izbori 1990. u općini Vukovar uglavnom su prošli mirno. Nešto je napetije bilo $\mathrm{u}$ selima $\mathrm{s}$ nacionalno mješovitim stanovništvom. Merčep i HDZ nisu imali povjerenja u predsjednika Općinskoga izbornog povjerenstva, suca Miloša Vojnovića, po nacionalnosti Srbina. Tražili su da u povjerenstvima u izbornim jedinicama s nacionalno mješovitim stanovništvom gdje bi rezultati mogli biti tijesni - u Srijemskim Čakovcima, Beraku, Sotinu i Borovo Naselju - budu i članovi odani HDZ-u. Pozvani su i međunarodni promatrači OESS-a (Pekić 1995: 37). Nakon izbora Merčep je tvrdio da je HDZ pokraden, ali je Vrhovni sud odbio žalbu HDZ-a.

\footnotetext{
Video-materijal, snimka u: Bitka za Vukovar, ep. 2 Nenaoružani odredi. https://www. youtube. $\mathrm{com} /$ watch? $\mathrm{v}=\mathrm{bkzq} 3 \mathrm{JTJqVg} \& \mathrm{t}=4 \mathrm{~s}$, uč. 4. ožujka 2019.

8 Video-materijal, izjava Vladimira Šeksa u: Bitka za Vukovar, ep. 2 Nenaoružani odredi. https://www.youtube.com/watch?v=bkzq3JTJqVg\&t=4s, uč. 4. ožujka 2019.
}

Iz općine Vukovar u tri doma Sabora SR Hrvatske izabrano je pet zastupnika - četiri iz SKH-SDP-a i jedan neovisan kandidat. Četvorica zastupnika bili su Hrvati, a jedan Srbin/Jugoslaven. Svi su bili na glasu kao osobe sklone suživotu i nacionalnim kompromisima. No većina su bili članovi stranke koja je u Saboru postala oporba. U predstojećem razdoblju nije bilo nevažno što Vukovar nije imao saborskog zastupnika iz HDZ-a.

SKH-SDP pobijedio je i u općini. U Skupštini općine dobio je 63 mjesta te je s osam vijećnika manjih socijalističkih stranaka i većinom neovisnih vijećnika lijevi blok imao dvotrećinsku većina u Skupštini, ali ne i u Društveno-političkom vijeću kao najvažnijemu skupštinom "domu". Uvjerljivu većinu u Skupštini općine dugovao je članovima Vijeća udruženog rada. Naime, zbog relativno kratkog roka za organizaciju izbora, HDZ nije uspio istaknuti kandidate u mnogima radnim organizacijama, pa kandidati SKH-SDP-a nisu imali prave protivnike u izbornoj utakmici.

Općinski vijećnici najčešće su bili birani prema nacionalnoj pripadnosti. U selima s hrvatskom većinom pobijedio je HDZ, a u selima sa srpskom većinom SKH-SDP, koji u njima nije ni imao prave protukandidate. U selima s rusinskom većinom, Mikluševcima i Petrovcima, pobijedio je također SKH-SDP. 
$\mathrm{U}$ sedam od osam izbornih jedinica $\mathrm{u}$ gradu Vukovaru pobijedio je SDP-SKH, a HDZ je pobijedio samo u mjesnoj zajednici na Mitnici.

I HDZ i SKH-SDP imali su razloga biti i zadovoljni i nezadovoljni izbornim rezultatima. HDZ je slavio pobjedu na nacionalnoj razini, ali je žalio zbog poraza u općini. Srpsko krilo SKH-SDP-a bilo je razočarano pobjedom HDZ-a u Hrvatskoj, ali su Srbi bili zadovoljni što je SKH-SDP osvojio vlast u Vukovaru pa su tvrdili kako je Vukovar rekao "ne" HDZ-u i pokazao da je "srpski grad" (Pekić 1995: 38). Hrvati koji su glasovali za SKH-SDP, umjereni Srbi i većina drugih građana bili su zabrinuti zbog pobjede HDZ-a u Hrvatskoj, ali su uglavnom bili zadovoljni rezultatima izbora $\mathrm{u} \mathrm{Vu-}$ kovaru i izborom tolerantnih vukovarskih zastupnika u Sabor (Mirković-Nađ 2011). Voljom većine vijećnika SKHSDP-a inženjer Slavko Dokmanović iz Trpinje postao je predsjednik Skupštine općine, dok je podpredsjednik postao mladi nezaposleni inženjer iz Lovasa Marin Vidić Bili iz HDZ-a. Izvršno vijeće općine nije bilo odmah izabrano.

\section{Srpska demokratska stranka}

Predizborne računice srpskih političara nisu više bile važne poslije izbora pa se moglo pristupiti osnutku srpske stranke. Na osnivačkom skupu SDS-a 10. lipnja 1990. u izletištu Adici okupilo se nekoliko tisuća ljudi koji su nosili zastave Jugoslavije, Srbije i Srpske pravoslavne crkve. Predsjednik SDS-a Jovan Rašković kazao je na skupu: "SDS je jedini zaklon koji neće dozvoliti da se zatre srpski narod u Hrvatskoj... SKH je izigrao Srbe i nema razlike između Tuđmana i Račana". Masa je oduševljeno klicala Raškoviću, Miloševiću, Srbiji i Jugoslaviji (VN, 11. i 16. lipnja 1990). Svi su osnivački skupovi SDS-a bili puni nacionalnog naboja i umnogome su nalikovali na skupove HDZ-a, ali su bili znatno mili- tantniji. U Boboti je 22. srpnja 1990, uz osnivačku skupštinu SDS-a, održan Svesrpski zbor Istočne Slavonije i Srijema na kojemu je Rašković pred oduševljenom masom ponovio zahtjeve za autonomijom i suverenošću Srba: "Ukoliko nam se taj suverenitet ne omogući, mi ćemo sami posegnuti, kao što smo kroz istoriju činili, da uspostavimo slobodu srpskom narodu u Hrvatskoj. Srbi u Hrvatskoj su spremni ginuti..." (VN, 4. kolovoza 1990). Na osnivačkoj skupštini SDS-a u Borovu u kolovozu 1990. na lokalnom stadionu okupile su se tisuće ljudi, a bilo je gosta iz Srbije i Bosne i Hercegovine. Zapaljive nacionalističke govore održali su Goran Hadžić i Momčilo Kosović iz Glavnog odbora SDS-a iz Beograda (VN, 25. kolovoza 1990).

$\mathrm{Na}$ čelu vukovarskog SDS-a našao se "čovjek koji je došao niotkuda", skladištar iz VUPIK-a, relativno mladi Goran Hadžić, koji je izabran na listi SKH-SDP-a u selu Pačetin. Njegov posao u skladištu VUPIK-a mnogima je bio predmet poruge, ali to mu je mjesto omogućavalo da se uplete u koruptivnu mrežu kao izvor moći i utjecaja (Judah 2000:152). Hadžića je za predsjednika SDS-a preporučio general Dušan Pekić, koji je potjecao iz vukovarskog kraja i imao je važnu ulogu u Organizaciji umirovljenih oficira JNA koja je služila Miloševiću.

Do kraja 1990. SDS je imao petnaest mjesnih odbora i više od pet tisuća ljudi uključenih u djelovanje. Organizacije SKH-SDP-a u Pačetinu i Boboti prešle su u SDS pa je tako dobio zastupnike u Skupštini općine. Prebjezi su svoj postupak pravdali time da ih je partija "izručila na tacni" Tuđmanu i da ne zastupa interese Srba (Glas Slavonije, 22. kolovoza 1990). I članovi SKH-SDP-a koji su pobijedili u izborima zahvaljujući i glasovima Hrvata prelazili su u SDS, kao što se dogodilo u Berku (Runtić 2010: 358). 
SKH-SDP pokušavao je zaustaviti osipanje članstva. Sekretar Predsjedništva Boris Malada posjetio je Trpinju kako bi odvratio članove od pridruživanju SDS-u. Predsjednik stranke Ivica Račan posjetio je Vukovar 23. lipnja, na sedamdesetu obljetnicu 2. kongresa KPJ, i održao govor na skupu u Adici na kojemu je kritizirao HDZ, zauzeo se za zadržavanje socijalističkih obilježja i isticao važnost ravnopravnosti Srba u Hrvatskoj (VN, 30. lipnja 1990). No vukovarski SKH-SDP sve se više fragmentirao, ponajviše zbog političkih procesa u Hrvatskoj i Jugoslaviji. Nakon niza razilaženja o bitnim pitanjima i povlačenja iz politike predsjednika Općinskog komiteta Darka Manojlovića, u Vukovaru je 20. studenoga 1990. promoviran SDP kao nova stranka. Predsjednik je postao Hrvat, saborski zastupnik Zlatko Modalek, a podpredsjednik Srbin Đorđe Macut. Stranci su ostati lojalni zastupnici u Saboru.

U Vukovaru su osnivani i ogranci novih lijevih i projugoslavenskih stranaka - Saveza reformskih snaga Jugoslavije, Socijalističke stranke Hrvatske, Socijalističke partije, Stranke Jugoslavena, Saveza komunista-Pokreta za Jugoslaviju i drugih - ali one nisu znatnije utjecale na politički život. Osnivani su i ogranci više hrvatskih stranaka - Hrvatske stranke prava, Hrvatske socijalno-liberalne stranke, Hrvatske kršćanske demokratske stranke i drugih - ali ni one nisu znatnije utjecale na politička zbivanja u vukovarskom kraju.

\section{Lokalna politika nakon izbora}

Neposredno poslije lokalnih izbora općinska tijela vlasti zapala su u krizu. Iz javnoga političkog života sukobi su se prenosili u institucije lokalne vlasti. $\mathrm{Na}$ prvim sjednicama Skupštine općine HDZ je optuživao SDP-SKH za malverzacije u vukovarskim poduzećima. Organizirao je štrajk radnika u Borovu nastojeći smijeniti upravu poduzeća (Filipović 2018). Merčep je stalno upozoravao na nacionalnu pripadnost vodećih ljudi u općinskim tijelima i poduzećima, koji su većinom bili Srbi. "Hrvati su", govorio je, "većina jedino na Birou za zapošljavanje" (VN, 18. kolovoza 1990). Vukovarski HDZ bio je frustriran time što nije preuzeo vlast u općini, a time i kontrolu nad lokalnima privrednim i društvenima resursima.

U srpnju 1990. političke je napetosti zaoštrilo usvajanje amandmana na Ustav SR Hrvatske. Skupština općine Vukovar većinom je odbacila ustavne amandmane, ponajviše zbog promjene ustavnog statusa Srba u Hrvatskoj i uklanjanja petokrake s republičke zastave. SDS je organizirao potpisivanje peticije protiv ustavnih amandmana. Sve hrvatske političke stranke kritizirale su tu praksu i isticale legitimnost republičkih vlasti, a HDZ je organizirao i potpisivanje peticije podrške ustavnim amandmanima (Glas Slavonije, 19, 20. i 23. srpnja 1990). I SDS i HDZ tvrdili su kako su prikupili tisuće potpisa, ali nema pouzdanih podataka o tome koliko je građana stvarno potpisalo te dvije peticije.

Dok je Sabor 25. srpnja 1990. usvajao amandmane na Ustav, predsjednik Skupštine općine Slavko Dokmanović pojavio se na Narodnom zboru u Srbu koji je organizirao SDS i na kojemu je proglašena suverenost Srba u Hrvatskoj. Štoviše, postao je član Srpskoga nacionalnog vijeća (SNV) (Barić 2005: 7273). Hrvatske stranke u Vukovaru optužile su Dokmanovića da se priklonio SDS-u, da podržava paralelnu vlast i da želi "libanonizaciju" Hrvatske (VN, 11. kolovoza 1990). Dokmanović se pravdao time da je sudjelovanjem na zboru želio smiriti uzavrele strasti, ali je kazao da je njegov odlazak na taj skup "tražio srpski narod općine". Tvrdio je kako SNV nije paralelna vlast nego tijelo koje štiti Srbe od kulturne asimilacije (VN, 4. 
kolovoza 1990). Dokmanovića je branio SDS, dok je središnjica SKH-SDP-a, njegove stranke, tražila da se distancira od događaja u Srbu i odustane od članstva u SNV-u.

Lokalni HDZ-a reagirao je oštro: ili će Dokmanović istupiti iz SNV-a, ili će HDZ istupiti iz Društveno-političkog vijeća Skupštine općine, blokirati rad općinskih tijela i izazvati nove izbore. HDZ se bojao da će Dokmanović priključiti Vukovar pobunjenim općinama u Lici i Dalmaciji. Pritisak HDZ-a i prijetnja novim izborima, kao i stav središnjice SKH-SDP-a prisilili su Dokmanovića da se javno odrekne članstva u SNV-u. Zauzvrat, HDZ je odustao od zahtjeva za njegovom ostavkom i obećao suradnju u formiranju općinske vlade. SDS je bio zadovoljan, jer su se Srbi mogli opetovano uvjeriti u to da SKH-SDP nije njihova stranka i da njihove interese najbolje štiti SDS. Dokmanović je ostao prilično izoliran od Hrvata, sve većeg broja Srba i pogotovo svoje stranke na čije se pozive iz Zagreba prestao odazivati (Vjesnik, 25, 28. i 29. kolovoza 1990; Politika, 22. kolovoza 1990).

U krajnje napetu ozračju, od 19. do 24 . kolovoza 1990, održan je referendum o srpskoj autonomiji koji je organizirao SDS. Referendum je proveden u seoskim domovima u selima s većinskim srpskim stanovništvom i u prigradskom naselju Lužac. U gradu se moglo glasovati samo u prostorijama Radničkog doma koje je zakupio SDS. Predsjednik povjerenstva za provedbu referenduma bio je predsjednik općinskog suda Petar Mrkšić (Pekić 1995: 41). Povjerenstvo je objavilo da se gotovo 100 posto glasača izjasnilo za uspostavu srpske autonomije. Prema izvješću, odaziv je bio izvanredan pa je, primjerice, u Negoslavcima glasovalo svih 1.452 birača (VN, 29. kolovoza 1990). Premda službeni rezultati referenduma pobuđuju sumnju, Srbi su svojim ponašanjem pokazali da su go- tovo svi bili za autonomiju. Razlikovali su se samo u tumačenjima onoga što bi ona u praksi značila: neki su mislili da bi donijela snažniju lokalnu samoupravu, dok su drugi mislili da je značila de facto pripajanje Srbiji.

Nakon referenduma i istupanja Dokmanovića iz SNV-a, stanje se donekle smirilo. No općinska vlast nije funkcionirala, a poslove su obavljali "stari kadrovi". Prema Poslovniku, Izvršno vijeće biralo se na sjednici svih triju skupštinskih vijeća natpolovičnom većinom glasova svih vijećnika, s time da je na sjednici morala biti najmanje dvotrećinska većina vijećnika. Kandidate su predlagali odbori ili najmanje dvadeset vijećnika. Mandat za sastav općinske vlade dobio je Mile Šusto, Hrvat, ali njegov prijedlog članova Izvršnog vijeća nisu podržali Općinski komitet i konzervativni vijećnici SKH-SDP-a. Novi kandidati postali su Stipo Lovrinčević i Milan Čorak, Hrvati jugoslavenske orijentacije, na glasu kao ortodoksni komunisti. Vijećnici HDZ-a nisu bili zadovoljni kandidatima pa su napustili sjednicu. Kvorum je ipak očuvan, a povjerenje je početkom listopada dobio Lovrinčević, koji je održao nastupni govor pun parola tipičnih za konzervativnu struju nekadašnjeg SKH (VN, 29. kolovoza 1990, 1. rujna 1990, 6. listopada 1990).

Istodobno je Općinski komitet SKHSDP-a izradio Deklaraciju o zajedničkom životu građana općine Vukovar. U njoj je, među ostalim, pisalo kako treba privesti kraju slavlja na jednonacionalnim okupljanjima i izbjegavati ponašanje koje iritira drugu stranu (VN, 6. listopada 1990). Izvršno vijeće predložilo je da se zbog sigurnosti i boljeg razumijevanja na pola godine obustave svi stranački skupovi u Vukovaru, ističući kako valja misliti i na trećinu stanovnika općine koji nisu ni Hrvati ni Srbi. SDS je ignorirao prijedlog, a HDZ je uzvratio prijedlogom da se raskinu sporazumi s 
bratskim gradovima u Srbiji, kao što je bilo Svetozarevo (VN, 8. prosinca 1990).

Iako je Općinski komitet SKH-SDP-a kritizirao "jednonacionalna okupljanja" i "poteze koji iritiraju druge", mnogo je kritičniji bio prema HDZ-u nego prema SDS-u. To dobro ilustrira pisanje njegova službenog glasila, Vukovarskih novina, kojima je glavni urednik bio Mirko Stanković, ujedno dopisnik beogradske Politike koja se potpuno uključila u ratnohuškačku kampanju. ${ }^{9}$ Vukovarske novine davale su značajan prostor srpskom krilu SKH-SDP-a, osnutak i djelatnosti SDS-a pratile su neutralno ili donekle afirmativno zato što "narod to podržava", a o aktivnostima HDZ-a pisale su vrlo malo i rezervirano. Relativno malo prostora dobivao je i SDP, koji je ostao lojalan središnjici u Zagrebu, a podupirane su stranke socijalističke i unitarističke orijentacije. ${ }^{10}$

\section{Vukovarski SDS poslije izbora}

Tijekom jeseni 1990. SDS je usko usklađivao svoje djelovanje $s$ političkim vodstvom Srbije. ${ }^{11}$ Početkom listopada 1990. skupina političara vukovarskog SDS-a, u kojoj su bili Goran Hadžić i Radivoje Kresojević, žalila se Borisavu Joviću, predsjedniku Predsjedništva SFRJ i predstavniku Srbije u tom tijelu, na vlast HDZ-a zbog narušavanja prava Srba u Hrvatskoj (VN, 6. listopada 1990). Predsjedništvo Srbije zatražilo je od Predsjedništva SFRJ "da zaštiti građane SFRJ srpske nacionalnosti od represalija kojima su izloženi u Hrvatskoj" (Marijan 2015: 284). To je bilo upravo ono što je vodstvo SDS-a željelo: izazvati reakci-

9 V. izvješća Stankovića iz Vukovara u beogradskoj Politici 1990-1991. O ulozi dnevnog lista Politika v. Thompson (1995).

10 V. brojeve Vukovarskih novina od početka 1990. do smjene uredništva u svibnju 1991.

11 ICTY/Cases/Stanisic\&Simatovic (IT-0369)/Witness: Borivoje Savic. ju saveznih vlasti koje bi mu pomogle da se Srbi "odcijepe" od Hrvatske.

U listopadu je na gradskom Trgu republike održan miting SDS-a na kojemu se okupilo oko dvije tisuće ljudi sa srpskim zastavama. Hadžić je u govoru okupljenima kazao: "Slavonija, Baranja i Srijem srpski su teritorij i to će ostati". Poručio je hrvatskim vlastima: "Ostavite na miru srpski narod. Srbinu nikada nije bilo strano ginuti jer Srbi su od pamtivijeka bili stradalnici i mučenici". Masa je izrazila solidarnost sa Srbima u Kninu. Čuli su se povici "Hoćemo oružje" i "Ovo je Srbija". Zahtijevalo se da savezna vlada i Srbija poduzmu mjere kojima će zaštititi interese srpskog naroda toga kraja (VN, 6. listopada 1990).

Dok se održavao skup SDS-a, aktivisti HDZ-a okupili su se oko stanice javne sigurnosti kako bi spriječili pristaše SDS-a da razoružaju policiju, kao što su učinili u drugim mjestima u Hrvatskoj. Merčep i vođe HDZ-a iz Osijeka i Zagreba smatrali su kako SDS mitingom pokušava ostvariti ono što nije uspjelo Dokmanoviću - priključiti Vukovar pobunjenim općinama. $\mathrm{Na}$ Trgu republike HDZ je u studenome organizirao miting "Potpore vrhovništvu RH" na kojemu se okupilo oko dvije tisuće ljudi. Miting je bio usmjeren protiv općinskog SDS-a, savezne vlade i vlade Srbije, kao i protiv općinske vlasti SKH-SDP-a. HDZ je želio preuzeti vlast u općini kako bi tako osigurao ostanak Vukovara u Hrvatskoj (VN, 28. studenoga 1990).

SDS je pak postajao politički sve isključiviji. U listopadu 1990. u Boboti je organizirana proslava tristote obljetnice seobe Srba u kojoj je veliku ulogu imala Srpska pravoslavna crkva, a u proslavi su sudjelovali srijemski episkop Vasilije, pjesnik Matija Bečković i drugi nacionalistički profilirani intelektualci iz Srbije. Proslava seobe Srba održana je i u Borovu Naselju gdje su gostovali knji- 
ževnici Jovan Radulović i Rajko Nogo, poznati po svojima nacionalističkim stavovima. Lokalna učiteljica čitala je svoje pjesme inspirirane Kosovom (VN, 6. listopada i 28. studenoga 1990). Nacionalni mitovi, protkani stalnim podsjećanjima na stradanja Srba u NDH, preuveličavanjem broja žrtava i prepričavanjem događaja $s$ morbidnim pojedinostima pridonosili su nacionalnoj mobilizaciji Srba. Govore političara SDS-a, posebno Gorana Hadžića, obilježavali su ekstremizam, militantnost i najave sudbonosnih događaja. ${ }^{12} \mathrm{Na}$ mitingu $\mathrm{u}$ listopadu Hadžić je pozdravio prisutne s "Pomoz bog, braćo Srbi". Jedna Srpkinja iz Vukovara prisjeća se: "Nikada pre, na javnoj sceni, nisam čula tu rečenicu. Poznavala sam je iz priče moje babe... u zatvorenoj sobi... Zimi sa nostalgijom se sećala da se tako srpski kralj obraćao svom narodu..." (Pekić 1995: 124). Otkrivani su stari nacionalni datumi i sjećanja, krsne slave i zaboravljeni, katkad i izmišljeni herojski preci. Srpsku Novu godinu 1991. vodstvo SDS-a proslavilo je uz četničke šubare, kokarde i pjesme (Karan 2016: 79).

SDS je jačao i na drugim područjima života i pretvarao se u svesrpsku stranku istočne Slavonije. Prikupljana je pomoć pobunjenicima u Dalmaciji. Mještani poljoprivredno bogatih Bobote i Borova donirali su poslije berbe trideset tona kukuruza Kninu. Hadžić je uz pomoć pristaša SDS-a uspio preusmjeriti velika financijska sredstva iz Veleprometa i VUPIK-a u izgradnju društvenog doma i nogometnog igrališta u Pačetinu te je sebi i SDS-u pribavio gotovo plebiscitarnu potporu mještana svoga sela $(\mathrm{VN}, 15$. prosinca i 17. travnja 1990).

SDS je opskrbljivao svoje pristaše u selima lakim oružjem koje je dobavljala

12 Goran Hadžić ponovio je svoje izjave u mnogim prigodama pa i u intervjuu novosadskom Dnevniku, 3. ožujka 1991.
Služba državne sigurnosti Srbije. ${ }^{13}$ Želio je potaknuti JNA da intervenira kako bi Srbi ostvarili svoje političke ciljeve. Kako je JNA bila neodlučna, Srbi su se počeli jače naoružavati, pri čemu su im značajno pomagali Ministarstvo unutarnjih poslova Srbije i kontraobavještajna služba JNA. Ubrzo su srpska sela postala prepuna oružja i druge vojne opreme (Karan 2016: 111).

Posljednji predratni miting SDS-a u Vukovaru održan je 2. veljače, i to bez dopuštenja policije. Pred više stotina ljudi pročitan je proglas kojim se daje podrška Predsjedništvu SFRJ i JNA i podsjeća na nužnost razoružanja "svih paravojnih formacija" u Hrvatskoj, pri čemu se mislilo na HDZ i rezervni sastav MUP-a, te zahtijeva povratak općinskog SUP-a u Vukovar kako bi se zadržala kontrola nad policijom i rješenje statusa radnika tvornice Borova (VN, 9. ožujka 1991; Glas Slavonije, 4. veljača 1991).

SDS je 7. siječnja 1991. u Šidskim Banovcima osnovao SNV za Slavoniju, Baranju i zapadni Srijem kao predstavničko tijelo Srba u tom dijelu Hrvatske (Glas Slavonije, 18. siječnja 1991). Regionalni SNV trebao je poboljšati koordinaciju rada SDS-a na širem području i ojačati srpsku pobunu. Bez obzira na to što je većina Srba u Slavoniji vjerojatno podržavala rad SNV-a, legitimnost toga tijela bila je krajnje upitna. No srpskim elitama i masama bila je nevažna izborna legitimnost, a važna je bila legitimnost koja se stjecala ratnima i državotvornim zaslugama. Vodstvo SNV-a zastupalo je ekstremne stavove i vodilo radikalnu politiku, usklađenu s obavještajnim krugovima iz Srbije. ${ }^{14}$ Istodobno, osnivanjem SNV-a slabio je institucionalni

13 ICTY/Cases/Stanisic\&Simatovic (IT-0369)/Witness: Borivoje Savic.

14 ICTY/Cases/Stanisic\&Simatovic (IT-0369)/Witness: Borivoje Savic; ICTY/Cases/ Dokmanović (IT-95-13a)/Witness: Ilija Koncarevic. 
okvir SDS-a u Vukovaru pa su političari SDS-a prepustili političku borbu SNV-u.

\section{Vukovarski HDZ poslije izbora}

HDZ je vodio lokalnu politiku kao da je pobijedio na izborima. Tako je Blago Zadro kao predsjednik HDZ-a u Mjesnoj zajednici "Bratstvo i jedinstvo", u kojoj je poražen u izborima, predložio da se ona preimenuje u "Alojzije Stepinac". Zadro je, uz to, kazao kako "ovdje mogu živjeti samo oni koji prihvaćaju Hrvatsku kao svoju domovinu" (Radoš i Šangut 2011:23). Na inicijativu HDZ-a i Katoličke crkve počelo je obilježavanje novih događaja, a ignorirani su događaji koje je slavila Jugoslavija. Na dotadašnji Dan borca 4. srpnja 1990. osječki i vukovarski HDZ organizirali su posjet Jazovki gdje su 1945. ubijeni vojnici NDH. Posjet je trebao biti vidljiv i glasan pa je organizirana kolona automobila koja je prošla kroz grad okićena zastavama (Glas Slavonije, 3. i 7. srpnja 1990).

Dan Republike 29. studenoga 1990. u Hrvatskoj nije obilježen. Vukovarski SDP bio je razočaran, a Skupština općine obilježila ga je u Radničkom domu (VN, 17. studenoga 1990). Slično je bilo i s obilježavanjem drugih događaja iz Drugoga svjetskog rata. U Iloku je 4. prosinca obilježavan dan kada su 1944. Crvena armija i partizani oslobodili grad, ali je proslava 1990. bila skromnija i svela se na polaganje vijenaca. HDZ je pritom položio vijenac i na mjesto na kojemu je nekoliko dana nakon oslobođenja grada 1944. strijeljano 48 Iločana, pripadnika oružanih snaga NDH i osoba koje su ondašnje vlasti smatrale "sumnjivima" (VN, 8. prosinca 1990). Na Mitnici je u siječnju 1991. osnovana udruga Hrvatskih ratnih veterana u kojoj su sudjelovali pripadnici domobranske vojske NDH (Glas Slavonije, 12. siječnja 1991).

Središnja kulturna aktivnost HDZ-a u Vukovaru 1990. bila je usmjerena na ob- novu rada Hrvatskog doma (Horvat i dr. 2007: 8-18). Lokalne vlasti nisu željele financirati tu kulturnu akciju pa je HDZ prikupio novac donacijama za obnovu zgrade. Svečana obnoviteljska sjednica društva Hrvatski dom održana je 14. prosinca 1990. U prepunoj dvorani Brane Crlenjak, glavni inicijator akcije, održao je govor u kojemu je istaknuo kako Hrvatski dom nije stranačko društvo nego želi okupiti Hrvate i animirati humanističku inteligenciju kako bi se spriječilo "odnarođivanje" Hrvata (Horvat i dr. 2007: 30-32). No svih devet članova predsjedništva društva bili su članovi ili otvoreni simpatizeri HDZ-a. HDZ je slijedio obrazac djelovanja SKH prema kojemu je morao biti uključen u sva kulturna zbivanja i imati kontrolu nad njima. Merčep je na osnivačkoj skupštini održao govor kakav je bio tipičan za dotadašnje partijske dužnosnike u kojemu je kulturi namijenjena politički "angažirana" uloga u ostvarivanju ciljeva partije (VN, 29. prosinca 1990).

Od siječnja 1991. u Hrvatskom domu doista je oživjela nacionalna kulturna scena. Obilježena je 320. obljetnica pogibije hrvatskih velikaša Zrinskoga i Frankopana koji su prikazani u skladu s novim nacionalnim imaginarijem (VN, 11. svibnja 1991). Posebnu pozornost izazvala je promocija knjige lokalnog povjesničara Jurja Lončarevića Hrvati u Srijemu u ožujku 1991, koja je dotad raspačavana potajno (VN, 9. ožujka 1991), a u kojoj autor izražava simpatije za poražene snage u Drugome svjetskom ratu. HDZ je utjecao i na druge načine na javni život pa je, primjerice, počeo podupirati nogometne klubove, kakav je bio "Metalac" iz Bogdanovaca koji je preimenovan u "Croatiju" (VN, 17. studenoga i 8. prosinca 1990).

Nakon osnivanja SDS-a i pojave seoskih straža u srpskim selima u lipnju 1990, vukovarski Hrvati smatrali su da se trebaju naoružati. Sabor u Srbu i po- 
buna u Kninu u ljeto 1990. učvrstili su to uvjerenje. Blago Zadro je zagovarao naoružavanje još početkom 1990. Do kraja ljeta organizacija HDZ-a u Borovu Naselju prikupila je nešto lovačkog oružja (Radoš i Šangut 2011: 19, 26). Merčep je od stranačkih struktura primio instrukcije da se treba naoružati i organizirati unutar HDZ-a. Još tijekom priprema za izbore on je organizirao "tehničku službu" u stranci u kojoj su ljudi formalno bili zaduženi za osiguravanje stranačkih skupova, ali je služba trebala postati mjesto naoružavanja pod kontrolom HDZ-a. ${ }^{15}$

Lako oružje koje je na crnom tržištu 1990. kupio general Martin Špegelj dopremljeno je u jesen 1990. i u Vukovar. U listopadu je dopremljeno stotinjak kalašnjikova u Borovo Naselje, koje je Zadro podijelio članovima HDZ-a. S oružjem su došle i iskaznice rezervnog sastava MUP-a koje su dijeljene zajedno s puškama. ${ }^{16}$ Oružje je na sličan način ubrzo dopremljeno i u Bogdanovce (Matković 1998: 36). Do kraja godine veća količina oružja došla je i na Mitnicu i podijeljena je članovima HDZ-a (Runtić 2010: 74). "Afera Špegelj" iz siječnja 1991. glasno je odjeknula u Vukovaru, među ostalim i zato što je na spornoj filmskoj snimci bio i Zvonko Ostojić, član tehničke službe HDZ-a u Vukovaru, koji je u filmu potvrdio da se HDZ u Slavoniji naoružava (Glas Slavonije, 29. siječnja 1991). Ostojić, osoba Merčepova povjerenja, vjerojatno je bio povezan s obavještajnim službama, a ubrzo je pronađen mrtav u svojem stanu u Borovu Naselju (Radoš i Šangut 2011: 30).

HDZ je u 1991. ušao više kao svehrvatski pokret, a manje kao politička stranka. Kao oporbena stranka u općini, nije mogao kontrolirati lokalnu politiku,

15 ICTY/Cases: Hadzic (IT-04-75)/Witness: Adam Rendulic.

16 ICTY/Cases: Milosevic (IT-02-54)/Witness: Aleksandar Vasiljević. ali je djelomice provodio republičku politiku. Vršio je pritisak na stare strukture moći u općini nastojeći ovladati njima. Oponašao je obrazac djelovanja SKH prema kojemu je trebalo ovladati što većim brojem segmenata društva i nametnuti interes vlastite partije kao interes cijele zajednice.

\section{Politička radikalizacija i krah institucija}

Skupština općine Vukovar radila je u sve napetijim uvjetima. U prosincu 1990. prihvatila je nacrt hrvatskog Ustava nakon duge rasprave. Pritom je bio ključan stav SDP-a da se nacrt prihvati uz niz amandmana. Odbornici SDS-a odbacili su nacrt Ustava i o njemu nisu željeli ni raspravljati, računajući na to da to ionako neće biti njihov Ustav. HDZ je tvrdio kako u Ustavu, osim Hrvata, ne treba spominjati druge narode (VN, 22. prosinca 1990). Novi Ustav bio je još jedan izgovor za srpsku pobunu, koja je jačala poslije osnutka SNV-a u siječnju 1991.

Ožujski događaji u Pakracu (Barić 2005: 114-115) donijeli su u vukovarski kraj val glasina. Iz srpskih sela pokrenut je prvi izbjeglički val. SDS i SNV poticali su psihozu među Srbima, a Miloševiću lojalni gradonačelnici vojvođanskih gradova organizirali su autobuse za prijevoz ljudi i prihvat izbjeglica. Kako je prenio novosadski Dnevnik 3. ožujka 1991, Goran Hadžić je kazao: "Progon Srba je očigledan, nama se spremaju novi jasenovci i ostala stratišta iz minulog rata". Općinska vlast nije podržavale te akcije, a Dokmanović je pozivao na razumno ponašanje, ali je njegova vjerodostojnost među Srbima oslabjela poslije istupanja iz SNV-a. ${ }^{17}$ Objavljeno je i zajedničko priopćenje SDP-a i HDZ-a, koje su potpisali svi saborski zastupnici iz općine, u kojemu je rečeno kako je strah u srpskim selima iracionalan i "izazvan

17 ICTY/Cases/Dokmanović (IT-95-13a)/Witness: Milenko Milinković 
djelovanjem pojedinaca van općine, a vjerojatno i izvan Hrvatske..." (Dnevnik, 6. ožujka 1991).

Vodstvo vukovarskog HDZ-a zabrinuto je bilo zbog tih događaja, bojeći se da će oni izazvati intervenciju JNA, pa je smatralo kako se treba pripremiti za obranu. Nakon što je iz Zagreba stigao naputak da se počnu organizirati "nenaoružani odredi", vukovarski HDZ je 10. ožujka na livadi pokraj Bogdanovaca organizirao postrojavanje tih odreda. Prema podacima organizatora, okupilo se od dvije do dvije i pol tisuće ljudi koji su osjećali opasnost i željeli su se uključiti obranu (Matković 1998: 29). Okupljanje je vodio Merčep, koji je najavio osnutak vojnih formacija. ${ }^{18}$ To je pak brinulo vukovarske Srbe. ${ }^{19}$

Novu veliku krizu izazvalo je uhićenje prvakâ vukovarskog SDS-a Gorana Hadžića i Bore Savića na Plitvicama 31. ožujka 1991. U Boboti, Borovu, Bršadinu i Negoslavcima napadnute su policijske ophodnje, pucalo se, skidane su hrvatske zastave i podizane barikade. $U$ tim su događajima sudjelovali članovi SDS-a, ali pobuna Srba bila je znatno šira. SNV Slavonije, Baranje i Zapadnog Srijema uputio je ultimatum hrvatskim vlastima da u roku od 24 sata povuku policiju s Plitvica i puste Hadžića i Savića na slobodu, inače će se "srpski narod podignuti na ustanak" (Vjesnik, 1. travnja 1991; Politika ekspres, 1. travnja 1991).

Ultimatum Zagrebu nije ni istekao, a SNV je 31. ožujka na sjednici u Borovu donio odluku o "prisajedinjenju SAO Slavonija, Baranja i Zapadni Srijem Autonomnoj pokrajini Vojvodi-

18 Video-materijal: Bitka za Vukovar, ep. 2 Nenaoružani odredi. https://www.youtube. com/watch? v=bkzq3JTJqVg\&t=4s, uč. 4 . ožujka 2019.

19 Osobna sjećanja na rat i druge oblike političkog nasilja: Ružica Spasić, snimka: www. osobnasjecanja.hr ni, odnosno Srbiji". Zatraženo je hitno sazivanje skupštine Vojvodine kako bi potvrdila pripajanje (Politika ekspres, 1. travnja 1991). Policajci srpske nacionalnosti u Vukovaru napustili su hrvatsku policiju, a glavnim krivcem za svoj postupak proglasili su HDZ: "Za šefove su postavljeni polupismeni Hrvati kojima je pripadnost HDZ-u jedina policijska kvalifikacija", pisalo je u pismu upućenu načelniku (Gulan 1996: 18).

Reakcija na plitvičke događaje pokazala je moć vodstva SDS-a. I Dokmanović je podsjetio na to da Hadžić kao vijećnik Skupštine općine ima imunitet i tražio je da bude pušten, jer je "hapšenje izazvalo reakciju", a tek nakon toga može biti provedena istraga kako bi se utvrdilo jesu li prvaci SDS-a nešto skrivili (VN, 6. travnja 1991). Hrvatske vlasti prihvatile su takvo stajalište i tri dana nakon uhićenja Hadžić i Savić pušteni su na slobodu u skladu s uvjerenjem ministra unutarnjih poslova Josipa Boljkovca da se posredstvom njih može amortizirati srpska pobuna (Boljkovac 2009: 235).

U Vukovaru su noćima odjekivale eksplozije i puškaranja. Merčepu sklon dio HDZ-a smatrao je kako se treba pripremiti za rat i zauzeti ključne položaje, bez obzira na pregovore i mirovne inicijative iz Zagreba. Predsjednik Izvršnog vijeća Stipo Lovrinčević i načelnik policije Slavko Sredoselec gotovo su svakodnevno obilazili minirane gostionice kojima su vlasnici bili Srbi i razgovarali s vukovarskim Srbima kojima je noću pucano na kuće. Govorilo se kako sve nerede u gradu stvara skupina od tridesetak ljudi. Općinske vlasti naglašavale su kako treba obvezati HDZ i SDS da spriječe ekstremno ponašanje svojih članova. Dogovoreno je da Radio Vukovar objavljuje izvješća policijske uprave kako bi se spriječilo kolanje dezinformacija (VN, 20. travnja 1991). 
Posebnu ulogu u širenju glasina imao je Slobodni tjednik koji je objavljivao imena vukovarskih Srba koji su navodno sudjelovali u oružanoj pobuni, postavljanju barikada i nacionalističkom huškanju. U tome nije bilo mnogo neistine, jer su mnogi doista činili ono što im se pripisivalo u tom listu. No među prokazanim imenima vrlo su često bili direktori i poslovođe lokalnih tvrtki, poput Borova, Vupika i drugih, a neki nisu imali previše veze s političkim događajima. Skupini koja se htjela dokopati kontrole nad gradskim poduzećima bila je to dobra prigoda da ih se dodatno prokaže i iznudi njihova smjena. Djelomice se i vukovarski HDZ oglašavao $\mathrm{u}$ Slobodnom tjedniku jer mu lokalni mediji, Radio Vukovar i Vukovarske novine, nisu bili dostupni. U travnju 1991. HDZ je potaknuo peticiju, koju je potpisalo nekoliko tisuća građana, za smjenu direktora i urednika lokalnog medija. Tvrdilo se kako postojeće vodstvo provodi "komunističko-jugoslavensku, odnosno unitarističko-srpsku" uređivačku politiku. Te su optužbe dobile na snazi kada se postojećoj peticiji pridružilo i nekoliko zaposlenika Radija Vukovar. Unatoč prijetnjama i pucanjima na obiteljske kuće, direktor Čorak i urednik Stanković nastavili su raditi po svome do 2. svibnja 1991. kada su članovi HDZ-a silom preuzeli Radio (VN, 20. travnja 1991; Dnevnik, 29. travnja 1991; Večernji list, 4. svibnja 1991).

Općinska vlast SDP-a i druge oporbene stranke za loše su stanje u općini optuživali HDZ i SDS. U pismu upućenom predsjedniku Tuđmanu 9. travnja upozorili su na to da su svi napori da se očuva mir obezvrijeđeni. Nisu imenovali krivce, ali su tvrdili kako su krivi naoružani pojedinci i republička vlast. Naglašavali su kako se još doprema oružje i dijeli civilima uz policijsko osiguranje. Zahtijevali su da se poduzme sve kako bi se spriječio rat, jer su događaji nadrasli lokalnu politiku (VN, 20. travnja 1991). Pritom su se razlikovali predsjednik Skupštine općine Dokmanović, koji je za sve krivio HDZ, i predsjednik Izvršnog vijeća Lovrinčević, koji je ukazivao na emisare iz Srbije u vukovarskom kraju. Iz Zagreba je u Vukovaru potaknut međustranački dijalog u koji se uključila i središnjica HDZ-a (VN, 6. travnja 1991).

U međuvremenu je Dokmanović otputovao u Beograd i uputio hitan poziv predsjedniku Predsjedništva SFRJ Borisavu Joviću da JNA odmah "izađe na teren" i uspostavi tamponsku između $\mathrm{Hr}$ vata i Srba kao jedini način da se spriječi krvoproliće. Ako se to ne dogodi, najavio je kako će i sam u Trpinji dizati barikade (Dnevnik, 10. travnja 1991). Vratio se u Vukovar neobavljena posla, a HDZ je zatražio njegovu smjenu i raspuštanje Skupštine općine.

Rad Skupštine općine u travnju 1991. obilježile su napetosti, uvrede i prekidi sjednica. Saborski zastupnici iz Vukovara uporno su pozivali na red, razum i poštivanje zakona. Neki vijećnici, najčešće iz SDP-a, optuživali su HDZ i SDS za stvaranje nepodnošljiva stanja. Na nekadašnji Dan oslobođenja Vukovara 12. travnja prekinuta je sjednica Vijeća mjesnih zajednica. Predstavnici mjesnih zajednica Bobote i Borova odbili su sjesti u vijećnicu dok je u njoj istaknut samo hrvatski grb, a nema srpskih nacionalnih obilježja (VN, 20. travnja 1991). Vijećnik Ilija Đurić iz Borova rekao je: "Mi na ovom teritoriju smo žrtve vrhovništva. Ako je u pitanju ova država koju oni stvaraju, srpski narod nju neće - neće ni čuti, ako treba svi će izginuti... Mi tražimo svoje svojim i referendumom ćemo se izjasniti..." Vijećnik iz Bogdanovaca komentirao je kako je vukovarska općina uvučena u opasan velikosrpski scenarij (Pekić 1995: 70). 


\section{Epilog i zaključak}

Relativna kooperativnost koju je SDS pokazao prema hrvatskim vlastima nestala je 1. svibnja 1991. kada je Hadžić odbio pomoći hrvatskoj policiji da izvrši očevid na mjestu ubojstva u Bršadinu. Dan poslije uslijedila je akcija hrvatske policije u Borovu u kojoj je ubijeno dvanaest hrvatskih policajaca. To je bila prekretnica u razvoju događaja.

Nakon 2. svibnja Dokmanović je prestao dolaziti na posao u Vukovar zato što se, kako je kazao, nije osjećao sigurnim. ${ }^{20}$ Tijekom ljeta postao je ministar poljoprivrede u vladi Srpske autonomne oblasti (SAO). Tako je legalno izabrani predsjednik Skupštine općine Vukovar postati ministar u vladi paradržave u istoj toj općini. Dokmanović je kasnije znatno radikalizirao svoja politička stajališta i završio na klupi Međunarodnog suda u Haagu. ${ }^{21}$

Skupština općine radila je poslije 2 . svibnja u krnjem sastavu. Dužnost predsjednika preuzeo je dotadašnji podpred-

20 ICTY/Cases: Dokmanovic(IT-95-13a)/Witness: Slavko Dokmanović.

21 Slavka Dokmanovića optužio je 1996. Međunarodni sud u Haagu za zločine protiv čovječnosti, kršenje pravila ili običaja ratovanja i teške povrede Ženevske konvencije. Uhitio ga je 1997. UNTAES-a. Dokmanović je bio prva osoba kojoj se sudilo za "slučaj Vukovar". Dva svjedoka teško su ga teretila, optuživši ga da je bio na Ovčari tijekom počinjenja teškoga ratnog zločina. Merčep je smatrao kako se Dokmanović nije trebao naći prvi na optuženičkoj klupi i nije u njemu vidio najgoreg zločinca. I drugi hrvatski dužnosnici bili su iznenađeni što se od svih vukovarskih Srba na optuženičkoj klupi našao upravo Dokmanović. Politički vrh podunavskih Srba, uključujući one koji su sudjelovali u procesu mirne reintegracije, angažirao se u njegovoj obrani, a odvjetnici su tvrdili da su našli alibi koji ga oslobođa optužbi za nazočnost događajima 19. studenoga 1991. Počinio je samoubojstvo u zatvoru 1998. prije izricanja presude. ICTY/Cases: Dokmanovic(IT-95-13a). sjednik Marin Vidić Bili. Predsjednik Izvršnog vijeća Stipo Lovrinčević zbog zdravstvenih se problema povukao iz političkog života. Neformalnu vlast u općini preuzeo je Tomislav Merčep, koji je 15. lipnja imenovan sekretarom na narodnu obranu. Ta je vlast opstala do 23. srpnja 1991. kada je Vlada imenovala Vidića povjerenikom za općinu Vuko$\operatorname{var}$ (Marijan 2013: 70).

U gradu je niknuo niz mirovnih inicijativa u kojima su sudjelovali bivši članovi SKH svih nacionalnosti, saborski zastupnici SDP-a, umjereni članovi HDZ-a i mnoge druge stranački neopredijeljene osobe. No događaji su otišli predaleko da bi ih lokalni mirovni aktivisti mogli zaustaviti.

Politički život u općini Vukovar u burnim vremenima 1990-1991. obilježili su napeti međunacionalni odnosi, nastanak političkih stranaka koje su više nalikovale na nacionalne pokrete i djelovanje ostataka struktura stare vlasti koja se nije snašla u novim okolnostima. SKH-SDP izgubio je vlast u Hrvatskoj, ali je pobijedio u Vukovaru, umnogome zahvaljujući glasovima Srba. I prije izbora 1990. u Općinskom komitetu SKHSDP-a bio je vidljiv rascjep na pristaše Račanove i Miloševićeve struje, koji je kulminirao nakon izbora. Stranka se u općini rascijepila i u gledanjima na srpsko pitanje u Hrvatskoj. Predsjednik Skupštine općine Slavko Dokmanović bio je znatno bliži Miloševićevu nego Račanovu političkom programu. Saborski zastupnici SKH-SDP-a nastojali su biti konstruktivni, ali je njihov utjecaj bio ograničen.

Poslije gubitka vlasti u Vukovaru, HDZ se usmjerio na stjecanje kontrole u društvu i pritisak na lokalne moćnike, primjerice direktore poduzeća. Djelovao je ponajprije kao svehrvatski pokret, a manje kao politička stranka. U predvečerje rata i ugroze hrvatske suverenosti, 
organizirao je naoružavanje i obranu Vukovara. Kao i u Hrvatskoj, vukovarski HDZ imao je svoje "jastrebove" i "umjerene" članove.

SDS je nastao poslije izbora. Nikad se u općini Vukovar nije natjecao u izbori- ma i rijetko je poštovao legalne institucije. Iako je bilo članova koji su smatrali da političku borbu treba voditi u Hrvatskoj, ubrzo je prevladala struja koja je zagovarala odcjepljenje od Hrvatske. SDS se profilirao kao militantni nacionalistički pokret iredentističkog karaktera. 


\section{Literatura}

Barić, Nikica. 2005. Srpska pobuna u Hrvatskoj. Zagreb: Golden marketing.

Boljkovac, Josip. 2009. Istina mora izaći van.... Zagreb: Golden marketing.

Cvek, Sven, Ivčić, Snježana, Račić, Jasna. 2015. Jugoslavensko radništvo u tranziciji: Borovo 1989. Politička misao. (52) 2: 7-34.

Cvikić, Sandra. 2016. Vukovar u drugoj polovici 20. stoljeća: društveni uzroci nasilja (Disertacija). Zagreb: Hrvatski studiji.

Filipović, Vladimir. 2018. Iz socijalizma u nacionalizam: Kombinat Borovo u političkim promjenama 1990. Politička misao. (55) 1: 34-52.

Gulan, Branislav. 1996. S obe strane pakla. Novi Sad: Stylos.

Horvat, Vlado i dr. 2007. Hrvatski dom u Vukovaru. Vukovar: Gradski muzej.

Ivanda, Stipe. 2010. Vukovar: od nade do beznađa. Osijek: Hrvatsko društvo logoraša srpskih koncentracijskih logora.

Judah, Tim. 2000. The Serbs: history, myth and destruction of Yugoslavia. London: Yale University Press.

Jurčević, Josip. (ur.). 2004. Vukovar '91: međunarodni odjeci i značaj. Zagreb: Institut društvenih znanosti Ivo Pilar.

Karaman, Igor. (ur.) 1994. Vukovar: vjekovni hrvatski grad na Dunavu. Koprivnica: Feletar.

Karan, Ljuban. 2006. Bio sam oficir KOS-a. Beograd: Vlastita naklada.

Knežević, Domagoj. 2015. Hrvatska demokratska zajednica od osnivanja do raskida s Jugoslavijom. (Disertacija). Zagreb: Hrvatski studiji.
Lončarević, Juraj. 1990. Hrvati u Srijemu. Zagreb: Vlastita naklada.

Marijan, Davor. 2008. Slom Titove armije. Zagreb: Golden marketing.

Marijan, Davor. 2013. Obrana i pad Vukovara. Zagreb: Hrvatski institut za povijest.

Marijan, Davor, 2017. Hrvatska 19891992.: Rađanje države. Zagreb: Hrvatski institut za povijest.

Matković, Ivan. 1998. Bogdanovci: vrata Vukovara. Zagreb: K. Krešimir

Mirković-Nađ, Alenka. 2011. Glasom protiv topova: mala ratna kronika. Zagreb: Jesenski i Turk.

Pekić, Liljana. 1995. Vukovar 1991: Predvorje pakla. Vukovar: Dobra volja.

Pole, Stipo i dr. 2008. Jake snage MUP-a - policija u obrani Vukovara 1991. Vinkovci: SN Privlačica.

Radoš, Ivica, Šangut, Zoran. 2011. Blago Zadro - prvi hrvatski general. Zagreb: Udruga pravnika Vukovar 1991.

Runtić, Davor. 2010. Tako smo branili Vukovar. Vinkovci: Vlastita naklada.

Šimunović, Zlatko. 2003. Vukovarski dnevnik. Zagreb: Školske novine.

Thompson, Mark. 1995. Kovanje rata: mediji u Srbiji, Hrvatskoj i Bosni i Hercegovini. Zagreb: Hrvatski helsinški odbor za ljudska prava.

Živić, Dražen. (ur.). 2011. Ilok i iločki kraj u Domovinskom ratu. Ilok: Grad Ilok.

Žunec, Ozren. 2007. Goli život: socijetalne dimenzije pobune Srba u Hrvatskoj. Zagreb: Demetra, sv. 1-2. 


\section{Party Politics in the Vukovar in 1990-1991}

Abstract This article provides an analysis of local politics in the Vukovar municipality, from the pluralization of the political party scene in Croatia that started in early 1990 to the breakdown of democratically elected local institutions in May 1991. This relatively short period was marked by strong political polarization of the two largest national communities in the municipality, the Croats and the Serbs. In the process, there were three parties that played key roles in the political arena and in national mobilization - the League of Communists of Croatia/the Party of Democratic Change (SKH/SDP), the Croatian Democratic Union (HDZ) and the Serb Democratic Party (SDS).

Key words Vukovar, political parties, local elections, party politics 